\title{
PELAKSANAAN UNDANG-UNDANG NOMOR 6 TAHUN 2011 TENTANG KEIMIGRASIAN MENGENAI TANGGUNG JAWAB PENJAMIN ATAS KEBERADAAN DAN KEGIATAN ORANG ASING DI BALI
}

\author{
Oleh: \\ Ngurah Mas Wijaya Kusuma ${ }^{1}$
}

\begin{abstract}
According to Article 1 (26) of the Laws Number 6/2011 concerning Immigration, the term guarantor is well known. The guarantor is a person or a corporation responsible for the existence and activities of foreigners while they are in Indonesia. The term guarantor, at the time when the Laws Number 9/1992 concerning Immigration come into force has been replaced with the term sponsor whose meaning is not far from the term guarantor. The purpose of a guarantor for certain foreigners is that there are parties who are responsible for them during their stay and activities in Indonesia and even the parties see to their going home when their stay permit ends or finance them in their process for going home if they are deported. The other purposes are to make their stays and activities beneficial and advantageous to the local community so that stability and public interests remain to be maintained. However, the reality field in Bali, many underwriters foreigners who are not responsible and do not obligations stipulated in law No.6 of 2011. Irresponsible guarantor can be seen from the caresless for the existence and activities of foreigners so often misuse a residence permit or concurrent positions without permission and is located in Indonesia exceeded the time limit given or overstayed. Guarantors obligations can not be seen from the number of foreigners who do not report any change of address to the immigration office.

This study is an empirical legal research based on under law No 6 of 2011 on immigration is associated with the fact that the field deskriptif qualitative approach. The research condected in the area that includes counties delinquent bali, Denpasar city, district and county Gianyar and Buleleng. Data is sourced research on primary data and secondary data. The main source of this study is that the guarantor strangers individual and corporate guarantor. Secondary data obtained from the immigration officer. Primery data and secondary data sources supported by primary legal materials that Undang-undang No.6 in 2011 and legislation on immigration. Data collection techniques used are interview techniques and questionnaire techniques.

Lack of responsibility of the quarantors of the existence and activities of foreigners, due to lack of knowledge will be the quarantor liable as quarantor in particular the activities of foreigners. Assume that the quarantor has a limited residence permit foreigners can work anywhere. Lack of responsibility of a quarantor is also caused by the still weak immigration law enforcement in investigating any criminal cases immigration. Quarantor responsibility for the existence and activities of foreigners in bali, yet runs effectiveness.
\end{abstract}

Keywords : guarantors, foreigners, limited stay permit and constant stay permit

Mahasiswa Magister Ilmu Hukum Universitas Udayana, Denpasar, Bali. Alamat Jalan Jayagiri XVII / 2 Denpasar, e-mail: - 


\section{PENDAHULUAN}

\subsection{Latar Belakang}

Sudah menjadi pengetahuan umum bahwa Pulau Bali memiliki keindahan alam, kebudayaan yang unik dan penduduknya yang ramah, menjadi daya tarik tersendiri bagi warga negara asing berkeinginan mengunjungi dan bertempat tinggal berlamalama di Bali. Meningkatnya kedatangan orang asing menjadikan Bali bergelimpangan dolar sehingga memacu penduduk luar datang ke Bali dengan tujuan dapat merubah kehidupan yang lebih baik. Tidak mengherankan saat ini penduduk di Bali menjadi heterogen terutama di daerah-daerah yang dekat dengan kawasan wisata.

Kehadiran wisatawan asing ke Bali disambut senyuman manis masyarakat Bali, yang sangat berharap terbukanya kesempatan kerja sehingga dapat merubah kehidupan kearah yang lebih baik. Harapan menjadi kenyataan karena pemerintah dalam upaya meningkatkan kegiatan perekonomian masyarakat Bali, membuat suatu kebijakan pengembangan pembangunan industri kepariwisataan. Meningkatkanya industri kepariwisataan di Bali saat ini akibat masuknya investasi asing dan penanam modal dalam negeri, membawa konsekuensikonsekuensi salah satunya akan memperkerjakan tenaga kerja asing dalam rangka memajukan kegiatan usahanya, maka saat ini di Bali banyak tenaga kerja asing.
Menurut data, jumlah tenaga kerja asing pemegang izin tinggal terbatas bulan Januari sampai dengan 31 Agustus 2013, sebanyak 3.406 orang dan orang asing pemegang izin tinggal tetap sebanyak 3 orang. ${ }^{2}$

Masuknya tenaga kerja asing, tentunya akan membawa hal yang positif maupun hal negatif. Segi positif, tenaga kerja asing bisa mengalihkan/transfer pengetahuan dan tehnologi kepada tenaga kerja Indonesia sebagai pendamping. Sisi negatif, kehadiran tenaga kerja asing akan menambah daya saing dalam memperebutkan kesempatan kerja bagi warga lokal. Sisi lain mengalirnya investasi asing secara tidak langsung akan menarik banyak tenaga kerja asing lainnya untuk bekerja secara tidak sah. ${ }^{3}$ Tidak sah maksudnya orang asing melakukan kegiatan bekerja tanpa memiliki visa dan izin untuk bekerja yang dikeluarkan pemerintah.

Kehadiran hukum sangat di butuhkan untuk dapat menyelesaikan gejala-gejala hukum yang terjadi di masyarakat. Pada tanggal 5 Mei 2011 diundangkanlah Undangundang Nomor 6 Tahun 2011 tentang Keimigrasian sebagai pengganti Undangundang Nomor 9 Tahun 1992. Berdasarkan Pasal 63 Undang-undang Nomor 6 Tahun 2011 tentang Keimigrasian, mengatur adanya

\footnotetext{
${ }^{2}$ Rekapitulasi Data Statistik Izin Tinggal Keimigrasian Berdasarkan Maksud Kedatangan Pada Kantor Imigrasi Di Bali.

${ }^{3}$ M.Iman Santoso, 2004, Perspektif Imigrasi Dalam Pembangunan Ekonomi dan Ketahanan Nasional, Jakarta, Universitas Indonesia, h. 83
} 
kewajiban memiliki penjamin bagi orang asing tertentu yang berada di wilayah Indonesia. Penjamin adalah orang atau korporasi yang bertanggung jawab atas keberadaan dan kegiatan orang asing selama berada di wilayah Indonesia. Tanggung jawab penjamin tidak sebatas hanya pada keberadaan dan kegiatan saja, penjamin juga bertanggung jawab membiayai proses pemulangan dari Indonesia apabila izin tinggalnya telah habis atau dikenai deportasi. Tujuan adanya penjamin bagi orang asing tertentu adalah agar ada pihak-pihak yang bertanggung jawab selama keberadaan dan kegiatan di Indonesia dan agar selama keberadaan dan kegiatan orang asing dapat memberikan manfaat dan keuntungan bagi masyarakat agar tetap terjagannya stabilitas dan kepentingan umum.

Agar tujuan tersebut terwujud, maka ditetapkanlah pedoman tingkah laku yang diatur dalam suatu kaedah hukum. Kaedah hukum tersebut antara lain mengenai tanggung jawab penjamin, kewajibankewajiban penjamin sebagaimana diatur dalam Pasal 63 Undang-undang Nomor 6 Tahun 2011 tentang Keimigrasian dan agar penjamin benar-benar mentaati tanggung jawab dan kewajiban-kewajiban tersebut dikuatkan dengan adanya sanksi-sanksi apabila melanggar ketentuan yang telah ditentukan.
Namun demikian dalam kenyataannya masih banyak penjamin yang tidak melaksanakan kewajibannya dan tanggung jawab selaku penjamin, yang mengakibatkan orang asing yang dijaminnya melakukan pelanggaran-pelanggaran hukum keimigrasian. Pelanggaran hukum keimigrasian tersebut berupa penyalahgunaan izin tinggal, berada di Indonesia melebihi batas waktu yang diberikan, tenaga kerja asing bekerja tanpa memiliki izin yang dikeluarkan pemerintah dan memberikan data yang tidak benar untuk memperoleh izin tinggal keimigrasian. Berdasarkan pemberitaan media elektronik Bali Post, tanggal 20 Maret 2013, memberitakan bahwa petugas menemukan 2 (dua) tenaga kerja asing melakukan kegiatan ilegal di Hotel Ocean Blue di Kuta, Bali. ${ }^{4}$

Menurut data pelanggaran hukum keimigrasian tahun 2012 di Bali, tercatat orang asing pemegang izin tinggal kunjungan yang melanggar peraturan keimigrasian berjumlah 83 (delapan puluh delapan) orang, terdiri dari penyalahgunaan izin tinggal sebanyak 10 kasus, Penjamin tidak memenuhi kewajiban untuk melaporkan setiap perubahan alamat sebanyak 7 kasus, orang asing berada di Bali melampaui batas waktu yang diizinkan sebanyak 13 kasus. Orang asing pemegang izin tinggal terbatas,

\footnotetext{
${ }^{4}$ Redaksi, 2012, Diminta Dua Naker Asing di Ocean Blue Diberhentikan, www.balipost.co.id/ mediadetail.php? module $=$ berita $\&$ kid $=2$ sid $=67286$, diakses tanggal 10 Juni 2013.
} 
melakukan kegiatan bekerja merangkap jabatan tanpa memiliki izin dari pemerintah sebanyak 15 kasus, penjamin yang tidak memenuhi kewajiban untuk melaporkan setiap perubahan status sipil dan alamat tinggal sebanyak 4 kasus dan orang asing berada di Indonesia melebihi batas waktu yang berikan sebanyak 33 kasus. ${ }^{5}$ Sebanyak 83 kasus pelanggaran hukum keimigrasian tersebut berakhir dengan tindakan administratif keimigrasian berupa mencantumkan nama dalam daftar pencegahan dan penangkalan dan deportasi dari wilayah Indonesia.

Kenyataan lainnya lagi, pelanggaran hukum keimigrasian tahun 2013 di Bali, tercatat sebanyak 63 kasus yang terdiri dari orang asing pemegang izin tinggal kunjungan yang melakukan penyalahgunaan izin tinggal sebanyak 13 kasus, berada di Bali melebihi batas waktu yang diberikan sebanyak 24 kasus dan tanpa memiliki dokumen dan visa yang sah sebanyak 2 kasus. Kemudian orang asing pemegang Izin tinggal terbatas yang melakukan pelanggaran hukum keimigrasian berupa berupa bekerja merangkap jabatan tanpa izin pemerintah sebanyak 8 kasus, berada melebihi batas waktu yang diberikan sebanyak 16 kasus dan 5 kasus melakukan

${ }^{5}$ Rekapitulasi Pelanggaran Keimigrasian Tahun 2012 di Bali, Sumber Kantor Imigrasi di Bali. tindak pidana umum. ${ }^{6}$ sebanyak 63 (enam puluh tiga) kasus tersebut semuanya berakhir dengan tindakan administratif keimigrasian berupa pencantuman nama dalam daftar pencegahan dan penangkalan dan deportasi ke luar wilayah Indonesia.

Sebagai akibat banyak orang asing dan tenaga kerja asing melakukan kegiatan bekerja tanpa dilengkapi dengan izin kerja, menimbulkan gugatan masyarakat Bali yang merasa resah dengan merajalelanya tenaga kerja asing sehingga peluang kerja masyarakat Bali terkikis, sebagai akibat dari masuknya investor asing yang lebih mengutamakan tenaga kerja asing daripada tenaga kerja lokal sehingga tenaga kerja lokal beralih bekerja ke luar negeri di kapal pesiar. Gugatan ditujukan kepada instansi terkait yang mengeluarkan kebijakan yang kurang menguntungkan tenaga kerja lokal. Ada jabatan-jabatan yang sebenarnya bisa dijabat tenaga kerja lokal tetapi diberikan kepada tenaga kerja asing, misal jabatan juru masak, manager restaurant dan manager spa, begitu juga dari segi pengawasan dirasa masih lemah sehingga banyak tenaga kerja asing melakukan kegiatan bekerja tanpa memiliki ijin dan bodong. ${ }^{7}$

${ }^{6}$ Rekapitulasi Pelanggaran Keimigrasian Tahun 2013 di Bali, Sumber Kantor Imigrasi di Bali

${ }^{7}$ Balipost, 2012, Naker Asing Merajalela, www.id.facebook.com/balipost, diakses tanggal 11 Februari 2014 
Istilah gugatan masyarakat dimaksudkan tidak bermakna sebagai gugat menggugat dengan beracara di lembaga peradilan, sebagaimana di katakan Tjok istri Putra Astiti dalam buku Desa Adat Menggugat dan Digugat, mengandung arti gugat dimaknai sebagai bentuk protes, klaim, ataupun perlawanan yang dilakukan oleh masyarakat adat terhadap kebijakan negara/pemerintah. ${ }^{8}$

Berdasarkan data tersebut, maka perlu mengkaji penyebab dari permasalahanpermasalahan diatas, dengan pertimbangan Pulau Bali menjadi icon pariwisata Indonesia sehingga penting dijaga keberlanjutannya jika keamanan tetap terjaga.

\subsection{Rumusan Masalah}

Berdasarkan latar belakang masalah, maka dapat di rumuskan masalah sebagai berikut yaitu : (1) Bagaimanakah efektivitas pelaksanaan Undang-undang Nomor 6 Tahun 2011 Tentang Keimigrasian terkait dengan tanggung jawab penjamin atas keberadaan dan kegiatan orang asing di Bali. (2) Faktorfaktor apa yang mempengaruhi tanggungjawab penjamin atas keberadaan dan kegiatan orang asing di Bali?

\subsection{Tujuan Penelitian}

Penelitian ini mempunyai dua tujuan yaitu tujuan umum dan tujuan khusus. Tujuan

\footnotetext{
${ }^{8}$ Tjok Istri Putra Astiti, 2010, Desa Adat Menggugat dan Digugat, Denpasar, Udayana University Press, h. 5.
}

umum untuk mengkaji dan menganalisis penjamin sebagaimana diatur dalam Undangundang Nomor 6 Tahun 2011 tentang Keimigrasian mengenai perilaku, sikap penjamin. Tujuan khususnya adalah untuk memahami, menjelaskan dan menganalisis pelaksanaan Undang-Undang Nomor 6 tahun 2011, mengenai tanggung jawab penjamin atas keberadaan dan kegiatan orang asing di Bali.

\section{METODE PENELITIAN}

Penelitian ini merupakan penelitian hukum empiris, yang menganalisis bekerjanya Undang-undang Nomor 6 Tahun 2011 tentang Keimigrasian dan Peraturan Pemerintah Nomor 31 Tahun 2013 Tentang Peraturan Pelaksanaan Undang-Undang Nomor 6 Tahun 2011 tentang Keimigrasian, di masyarakat mengamati reaksi dan interaksi ketika sistem hukum bekerja di dalam masyarakat dengan pendekatan kualitatif. Penelitian hukum ini bersifat deskriptif yang menggambarkan secara rinci sifat individu, keadaan, gejala atau kelompok tertentu atau untuk menentukan penyebaran gejala atau untuk menentukan ada tidaknya hubungan antara suatu gejala dengan gejala lain dalam masyarakat. Data yang di pergunakan dalam penelitian ini adalah data primer dan data sekunder. Data primer diperoleh dari sumber utama yakni penjamin perorangan dan penjamin korporasi. Data sekunder diperoleh petugas imigrasi selaku pemegang peranan 
(role occupant) kemudian data primer dan data sekunder didukung pula dengan bahan hukum primer, sekunder dan tersier. Bahan hukum primer adalah bahan hukum yang memiliki kekuatan hukum mengikat, seperti Undang-Undang Nomor 6 Tahun 2011 Tentang Keimigrasian, Undang-Undang Nomor 13 Tahun 2013 Tentang Ketenagakerjaan dan Peraturan Pemerintah Nomor 31 Tahun 2013 tentang Peraturan Pelaksanaan Undang-Undang Nomor 6 Tahun 2011 tentang Keimigrasian. Bahan hukum sekunder diperoleh dari bahan hasil penelitian, teks, jurnal ilmiah dan media elektronik. Bahan hukum tersier diperoleh dari kamus-kamus dan ensiklopedia. Teknik pengumpulan data yang digunakan adalah tehnik wawancara dan tehnik kuesioner. Tehnik wawancara dimaksudkan melakukan tanya jawab secara langsung antara peneliti dengan penjamin orang asing selaku responden dan petugas imigrasi selaku informan. Pengumpulan data juga dilakukan dengan tehnik kuesioner yaitu suatu kegiatan dengan memberikan selembar pertanyaan kepada responden, dengan cara mendatangi masing-masing responden ke rumah dan kantor, agar mengisi dan diselingi dengan pertanyaan tidak berencana secara singkat dan sebagian kuesioner disebarkan melalui bantuan orang lain.

\section{HASIL DAN PEMBAHASAN}

\subsection{Pelaksanaan Undang-Undang Nomor 6 Tahun 2011 Mengenai Tanggung Jawab Penjamin Atas Keberadaan dan Kegiatan Orang Asing di Bali}

Menurut kamus lengkap bahasa Indonesia, pelaksanaan berarti proses dan cara melaksanakan. ${ }^{9}$ Sehingga dapat dikatakan pelaksanaan Undang-undang merupakan suatu proses dalam mengimplementasikan hukum yang bersifat pasif menjadi aktif untuk mencapai tujuan dari ide-ide pembuat hukum melalui peranan manusia. Hukum adalah teks dan ia hanya dapat menjadi aktif melalui campur tangan manusia. ${ }^{10}$ Untuk melihat aktivitas hukum dalam kenyataanya di perlukan mobilisasi hukum sehingga hukum berubah dari atas kertas menjadi hukum yang sesungguhnya atau nyata.

Hukum keimigrasian merupakan bagian dari hukum administrasi negara yang menjalankan pemerintahan dalam arti sempit. Van Vollenhoven mengartikan pemerintahan dalam arti sempit ialah hanya badan pelaksana (executive, bestuur) saja, tidak termasuk badan perundang-undangan, badan peradilan dan badan kepolisian. ${ }^{11}$ Institusi

\footnotetext{
${ }^{9}$ Tim Prima Pena, Kamus Lengkap Bahasa Indonesia, Gita Media Press, h. 402.

${ }^{10}$ Satjipto Rahardjo, 2010, Sosiologi Hukum; Esai-Esai Terpilih, Yogyakarta, Genta Publishing, h. 71 .

${ }^{11}$ H. Sadjijono, 2011, Bab-bab Pokok Hukum Administrasi, Yogyakarta, LaksBang Pressindo, h. 50 .
} 
imigrasi sebagai pelaksana Undang-undang Nomor 6 Tahun 2011, selalu berpedoman pada konsep Trifungsi Imigrasi sebagai landasan operasional untuk mencapai tujuan organisasi.

Trifungsi Imigrasi terdiri dari fungsi pelayanan keimigrasian, penegakan hukum dan keamanan negara serta fasilitator pembangunan kesejahteraan masyarakat. Fungsi pelayanan keimigrasian adalah memberikan pelayanan yang prima kepada warga negara Indonesia dalam bentuk pemberian Dokumen Perjalanan Republik Indonesia, pemberian affidavit bagi anak yang berkewarganegaraan ganda terbatas dan pelayanan pemberian tanda keluar atau masuk dari wilayah Indonesia kemudian pelayanan keimigrasian kepada warga negara asing dalam bentuk pemberian izin-izin keimigrasian, pemberian dokumen keimigrasian serta tanda masuk dan tanda keluar dari wilayah Indonesia. Fungsi penegakan hukum, dilakukan dengan menegakkan hukum kepada setiap orang yang berada dan melakukan kegiatan yang bertentangan dengan hukum yang berlaku, seperti pertanggungjawaban penjamin, pemalsuan identitas diri dan pelanggaran aturan keimigrasian. Fungsi keamanan serta fasilitator pembangunan kesejahteraan masyarakat, berupa melakukan tindakan pencegahan keluar Indonesia atas permintaan instansi terkait, seleksi terhadap setiap permohonan izin-izin keimigrasian, kerjasama dengan instansi terkait dan operasi intelijen keimigrasian kemudian bentuk fasilitator pembangunan kesejahteraan masyarakat dalam bentuk penyederhanaan prosedur keimigrasian bagi para investor asing yang akan menanamkan modalnya di Indonesia dengan cara kemudahan pemberian izin tinggal tetap dan kebijakan pemberian fasilitas Visa Kunjungan Saat Kedatangan bagi negara-negara maju.

Mekanisme pelaksanaan pemberian izin tinggal kunjungan diberikan oleh pejabat imigrasi di Tempat Pemeriksaan Imigrasi sesuai visa kunjungan yang dikeluarkan oleh perwakilan Indonesia di luar negeri untuk berada di Indonesia paling lama 60 hari. Izin tinggal kunjungan tersebut dapat diperpanjang paling banyak 4 (empat) kali dan jangka waktu setiap perpanjangan paling lama 30 hari. Pelaksanaan pemberian perpanjangan izin tinggal kunjungan, berkas permohonan diajukan kepada Kantor Imigrasi yang wilayah kerjanya meliputi tempat tinggal orang asing, dengan melampirkan persyaratan yaitu surat penjaminan dari penjamin pada saat mengajukan permohonan visa dan paspor yang sah dan masih berlaku. Pelaksana hukum akan menerima dan meneliti surat penjaminan dengan cara mencocokan penjamin yang tercantum pada visa dalam paspor orang asing. Kenyataan di lapangan dalam proses penelitian penjamin 
akan timbul dua masalah, pertama visa kunjungan yang tidak mencantumkan nama penjamin. kedua, visa kunjungan mencantumkan nama penjamin tetapi surat penjaminan ditandatangani oleh pihak yang tidak tercantum dalam visa kunjungan.

Pelaksanaan pemberian perpanjangan izin tinggal kunjungan pada Kantor Imigrasi di Bali, dalam hal menyelesaikan permasalahan surat penjaminan dari penjamin ternyata masing-masing memberikan kebijakan yang berbeda-beda sehingga dapat dikatakan belum mengikuti prosedurprosedur formal yang ditentukan dalam Pasal 140 Peraturan Pemerintah Nomor 31 Tahun 2013 tentang Peraturan Pelaksanaan Undangundang Nomor 6 Tahun 2011 tentang Keimigrasian. Pelaksanaan pemberian perpanjangan izin tinggal kunjungan pada Kantor Imigrasi Ngurah Rai, bahwa pemberian perpanjangan izin tinggal kunjungan pada dasarnya wajib melampirkan surat penjaminan dari penjamin yang mengajukan visa kunjungan tersebut namun demikian apabila visa kunjungan tidak mencantumkan nama penjamin maka surat penjaminan dapat ditandatangani oleh pihak lain yang bersedia menjadi penjamin orang asing tersebut. Kemudian apabila surat penjaminan ditandatangani oleh pihak yang tidak tercantum pada visa kunjungan maka penjamin yang mengajukan visa dapat memberikan surat kuasa kepada pihak lain sebagai penjamin, hal ini dapat terjadi apabila keberadaan penjamin dengan orang asing yang dijaminnya berada di suatu tempat yang berbeda. misalnya penjamin berada di Jakarta sedangkan posisi orang asing yang dijaminnya berada di Bali.

Pelaksanaan perpanjangan izin tinggal kunjungan lainnya pada Kantor Imigrasi Denpasar, pada dasarnya mewajibkan adanya surat penjaminan dari penjamin yang mengajukan visa, namun masih adanya perwakilan Indonesia di luar negeri yang mengeluarkan visa kunjungan tidak mencantumkan penjamin, maka sebagai pengganti surat penjaminan harus melampirkan surat bukti permohonan visa kunjungan. Kemudian apabila penjamin dan orang asing yang dijaminnya berada di suatu tempat yang berbeda, maka orang asing tetap melampirkan surat penjaminan dari penjamin yang mengajukan visa tersebut. Pelaksanaan lainnya pada Kantor Imigrasi Singaraja, pada dasarnya wajib melampirkan surat penjaminan dari penjamin yang mengajukan visa, namun ditemukan permasalahan seperti nama penjamin tidak tertera dalam visa dan penjamin berada ditempat yang berbeda dengan orang asing, maka pemberian perpanjangan izin tinggal kunjungan dapat diberikan apabila ada surat penjaminan yang pada prinsipnya ada pihak-pihak yang menjamin selama keberadaannya. 
Patut dipahami bahwa pelaksana hukum imigrasi, dalam pemberian perpanjangan izin tinggal kunjungan dalam hal penentuan penjamin mengambil kebijakan-kebijakan didasarkan atas belum adanya aturan yang menentukan penolakan pemberian izin tinggal kunjungan karena surat penjaminan. Mestinya ada ketentuan yang mengatur mengenai kreteria-kreteria penjamin sehingga ada pedoman bagi pelaksana hukum dalam menentukan penjamin orang asing pemegang izin tinggal kunjungan sehingga ada kepastian hukum. Belum adanya pengaturan tersebut maka dapat mempengaruhi kepatuhan penjamin akan kewajiban-kewajiban dan tangungjawabnya atas orang asing yang dijaminnya.

Pelaksanaan pemberian izin tinggal terbatas dan izin tinggal tetap pada Kantor Imigrasi di Bali, pada umumnya sudah berjalan dengan baik sesuai dengan peraturan yang berlaku. Namun demikian timbul masalah berkaitan dengan kewajibankewajiban penjamin. Kewajiban penjamin sebagaimana diatur dalam Pasal 63 ayat (2) Undang-undang Nomor 6 Tahun 2011, menyebutkan bahwa penjamin memiliki kewajiban untuk melaporkan setiap perubahan mengenai identitas diri dan atau keluarga orang asing yang dijaminnya dan setiap perubahan status sipil, kewarganegaraan, pekerjaan atau perubahan alamat.

Dalam rangka untuk mengetahui pemahaman penjamin akan kewajibankewajibannya, maka dilakukan Wawancara dengan Gito selaku penjamin korporasi di Bali, diperoleh keterangan bahwa penjamin memiliki keterbatasan-keterbatasan untuk memantau seluruh kegiatan orang asing yang dijaminnya. Sehingga dapat dikatakan bahwa penjamin belum melaksanakan kewajibankewajibannya secara maksimal. Hal ini juga dapat diketahui dari keterangan kepala subseksi penindakan keimigrasian pada kantor imigrasi Denpasar, yang sedang menangani orang asing pemegang izin tinggal terbatas yang diduga melakukan kegiatan tanpa izin dari pemerintah, menyampaikan bahwa penjamin tidak dapat memantau sepenuhnya kegiatan orang asing di luar jam kerja, begitu pula orang asing yang dijaminnya mengatakan bahwa dengan memiliki izin tinggal terbatas dan izin kerja pada jabatan tertentu dapat melakukan kegiatan pada jabatan lain.

Untuk mengetahui dan memahami penjamin atas kewajiban-kewajiban dan tanggung jawabnya, maka dilakukan penyebaran kuesioner kepada 34 responden selaku penjamin, di peroleh data bahwa penjamin pada umumya mengetahui adanya Undang-undang keimigrasian yang baru, namun demikian sebanyak 24 responden 
tidak mengetahui apa kewajiban-kewajiban penjamin dan hanya 10 responden yang mengetahui kewajiban-kewajiban selaku penjamin. Berkaitan dengan pemahaman akan arti tanggung jawab keberadaan dan kegiatan orang asing, hanya 2 responden paham arti tanggung jawab atas keberadaan dan kegiatan orang asing sedangkan sebanyak 32 responden tidak mengerti dan paham akan arti tanggung jawab atas keberadaan dan kegiatan orang asing. Berdasarkan hasil kuesioner tersebut dapat didapatkan gambaran bahwa penjamin belum memahami akan kewajibannya - kewajiban dan tanggung jawab atas keberadaan dan kegiatan orang asing selama berada di Indonesia sebagaimana di inginkan Undang-undang Nomor 6 Tahun 2011 tentang Keimigrasian.

Pelaksanaan Undang-undang Nomor 6 tahun 2011 mengenai tanggung jawab penjamin atas keberadaan dan kegiatan orang asing di Bali, selain mengkaji pelaksanaan tata cara dan pelaksanaan kewajibankewajiban penjamin juga penting untuk melihat pelaksanaan sanksi-sanksi bagi penjamin dan orang asing yang tidak mentaati peraturan yang berlaku. Sanksi adalah suatu nestapa yang dijatuhkan kepada siapa saja yang dinyatakan tidak mematuhi apa yang telah dinyatakan sebagai hukum yang berlaku. $^{12}$ Sanksi dalam Undang-undang
Nomor 6 ahun 2011 tentang Keimigrasian terdiri dari sanksi administratif keimigrasian dan tindak pidana keimigrasian. Tindak administratif keimigrasian adalah sanksi administratif yang ditetapkan pejabat imigrasi terhadap orang asing diluar proses peradilan. Tindak pidana keimigrasian atau tindakan pro yustisia adalah penyelesaian tindak pidana lewat proses peradilan.

Tindakan administratif dijatuhkan kepada orang asing yang melakukan pelanggaran Pasal 75 Undang-undang Nomor 6 tahun 2011, dan tindakan pro yustisia dikenakan apabila melakukan tindak pidana keimigrasian. Namun demikian dalam pelaksanaan sanksi, penegak hukum imigrasi selaku Pejabat Penyidik Negeri Sipil Imigrasi dalam menangani penyelesaian kasus tindak pidana keimigrasian penekanannya pada tindakan administratif keimigrasian sehingga belum terwujudnya efek jera sebagaimana di masudkan dalam undang-undang keimigrasian. Sehingga memberikan gambaran yang jelas bahwa kinerja Pejabat Penyidik Pegawai Negeri sipil Imigrasi dalam menjalankan fungsi sebagai penyidik tindak pidana keimigrasian untuk diproses dalam sistem peradilan pidana belum sebanding dengan proses tindakan administratif keimigrasian. 
3.2 Faktor-Faktor Yang Mempenga-ruhi Tanggung Jawab Penjamin Atas Keberadaan dan Kegiatan Orang Asing di Bali

Hukum dipakai sebagai pedoman untuk bertingkah laku dalam masyarakat dan ditujukan untuk merubah perikelakuan masyarakat sesuai dengan tujuan-tujuan yang telah ditetapkan sebelumnya.

Berkaitan dengan pelaksanaan Undangundang Nomor 6 Tahun 2011 tentang Keimigrasian mengenai tanggung jawab penjamin atas keberadaan dan kegiatan orang asing di Bali, mengalami hambatan yang disebabkan oleh beberapa faktor yaitu faktor substansi hukum, struktur hukum dan budaya hukum.

Institusi imigrasi memiliki landasan operasional dalam melaksanakan tugas dalam konsep Trifungsi Imigrasi. Dalam melaksanakan fungsi pelayanan institusi imigrasi mengacu pada hukum yakni Undang-undang Nomor 6 Tahun 2011 tentang Keimigrasian, dalam hal ini pelayanan pemberian izin tinggal kunjungan, izin tinggal terbatas dan izin tinggal tetap. Terselenggaranya fungsi pelayanan tercermin dengan adanya permintaan izin tinggal keimigrasian dari penjamin orang asing.

Faktor yang mempengaruhi impotensi tanggung jawab penjamin, dapat dilihat dari substansi hukum, yakni dalam Pasal 63 ayat 1 Undang-undang Nomor 6 Tahun 2011 tentang Keimigrasian menyebutkan orang asing tertentu yang berada di Indonesia wajib memiliki penjamin yang menjamin keberadaan dan kegiatan orang asing, dalam penjelasan pasal tersebut, menyebutkan bahwa orang asing tertentu adalah orang asing pemegang izin tinggal terbatas dan izin tinggal tetap. Ternyata dalam pasal 140 Peraturan Pemerintah Nomor 31 Tahun 2013 tentang Peraturan Pelaksana Undang-undang Nomor 6 Tahun 2011 tentang Keimigrasian, menyebutkan salah satu persyaratan permintaan perpanjangan izin tinggal kunjungan wajib melampirkan surat penjaminan dari penjamin pertama. Sehingga dapat di katakan orang asing pemegang izin tinggal kunjungan diwajibkan juga memiliki penjamin. Hal ini bertentangan dengan Pasal 7 Undang-undang Nomor 12 Tahun 2011 Tentang Pembentukan Peraturan Perundangundangan, yang menyebutkan "jenis dan hierarki peraturan perundang-undangan terdiri atas (1) UUD 1945, (2) Ketetapan MPR, (3) Undang-Undang/Perpu, (4) Peraturan Pemerintah, (5) Peraturan Presiden, (6) Perda Provinsi dan (7) Perda Kabupaten/ Kota. Dengan demikian dapat dikatakan bahwa adanya kewajiban penjamin bagi orang asing pemegang izin tinggal kunjungan telah terjadi norma konflik dan tidak diikuti asas lex superior derogat legi inferiori.

Berlakunya Undang-undang Nomor 6 Tahun 2011 tentang Keimigrasian, terdapat beberapa asas yang mengaturnya agar 
pelaksananya menimbulkan dampak positif. Salah satunya asas proporsionalitas dalam pelaksanaan fungsi keimigrasian, dan salah satu fungsi tersebut yaitu fungsi penegakan hukum dimana keseluruhan aturan hukum harus ditegakkan secara konsisten, konsekuen dan tegas. Peraturan Pemerintah Nomor 31 Tahun 2013 merupakan aturan pelaksana yang bersumber dari Undang-undang Nomor 6 Tahun 2011. Pengertian sumber hukum dikaitkan dengan alasan keabsahan suatu aturan hukum, dalam pengertian ini dapat dirujuk bahwa semua norma atau kaidah hukum yang lebih tinggi merupakan sumber hukum bagi kaidah hukum yang lebih rendah. $^{13}$

Penjamin bertanggung jawab atas keberadaan dan kegiatan orang asing selama berada di wilayah Indonesia, sebagaimana dirumuskan dalam pasal 63 ayat 2 Undangundang Nomor 6 Tahun 2011 tentang Keimigrasian, hanya mengatur kewajiban penjamin, untuk melaporkan apabila ada perubahan status sipil, status keimigrasian dan perubahan alamat, tetapi belum mengatur mengenai kewajiban penjamin atas kegiatan orang asing yang dijaminnya. Hambatan dalam meminta pertanggung jawaban penjamin juga di sebabkan ketidak jelasan arti kata keberadaan dan arti kegiatan. Hal ini berkaitan dengan hasil kuesioner responden

${ }^{13}$ I Dewa Gede Atmadja, 2012, Hukum Konstitusi; Problema Konstitusi Indonesia Sesudah Perubahan UUD 1945, Malang, Setara Press, h.7. dimana penjamin yang mengerti dan memahami arti keberadaan dan kegiatan orang asing hanya 2 responden dan yang tidak mengerti dan tidak memahami arti keberadaan dan kegiatan orang asing sebanyak 32 responden.

Faktor lainnya yang mempengaruhi tanggung jawab penjamin yakni struktur hukum (legal structure), dalam hal ini penegak hukum imigrasi yang melaksanakan hukum keimigrasian menjadi kenyataan. Secara sosiologis setiap penegak hukum mempunyai kedudukan (status) yang berisikan hak-hak dan kewajiban-kewajiban tertentu, yang dinamakan pemegang peranan (role occupant). Peranan dapat dijabarkan ke dalam unsur-unsur sebagai berikut : peranan yang ideal ( ideal role ), (2) peranan yang seharusnya (expected role), (3) peranan yang dianggap oleh diri sendiri (perceived role), dan (4) peranan yang sebenarnya dilakukan (actual role). ${ }^{14}$

Penegak hukum imigrasi mempunyai kedudukan sebagai pejabat penyidik pegawai negeri sipil untuk mengambil tindakan hukum bagi pelanggar tindak pidana keimigrasian. Sebagai penegak hukum PPNS Imigrasi memiliki "peranan yang seharusnya" (expected role), sebagaimana dirumuskan dalam Pasal 105 Undang-undang Nomor 6 tahun 2011, yakni berwenang menerima

\footnotetext{
${ }^{14}$ Soerjono Soekanto, 2011, Faktor-Faktor Yang Mempengaruhi Penegakan Hukum, Jakarta, PT Rajagrafindo Persada, h. 20.
} 
laporan,mencari keterangan dan alat bukti, memanggil memeriksa, menggeledah memeriksa menangkap, menahan sampai dengan penyerahan berkas kepada penuntu umum. Namun demikian pada umumnya penegak hukum imigrasi dalam menangani pelaku pelanggar hukum keimigrasian memainkan "peranan yang sebenarnya dilakukan" (actual role) dalam menangani kasus tindak pidana keimigrasian, misalnya penyalahgunaan izin tinggal, proses penyelesaiannya dengan memberikan tindakan administratif keimigrasian. Penegak hukum mengambil keputusan tindakan administratif keimigrasian karena didasari atas anggapan bahwa perbuatan orang asing tersebut dapat membahayakan dan patut diduga akan membahayakan keamanan dan ketertiban umum dan tidak menghormati atau mentaati peraturan perundang-undangan yang berlaku, sebagaimana di atur dalam Pasal 75 Undang-undang Nomor 6 Tahun 2011 tentang Keimigrasian.

Faktor terakhir yang mempengaruhi tanggung jawab penjamin adalah faktor budaya hukum (legal culture). Budaya hukum dimaksudkan pendapat masyarakat mengenai hukum yang mempengaruhi ketaatan masyarakat. Hal ini berkaitan dengan substansi hukum dan struktur hukum. substansi hukum dimaksud kurang jelasnya arti kata keberadaan dan kegiatan orang asing, tidak jelasnya mengenai kreteria penjamin dan adanya anggapan penjamin bisa di lakukan oleh siapa saja. Begitu juga halnya dengan struktur hukum, dimana penegak hukum lebih banyak memberikan sanksi administratif keimigrasian dari pada tindakan pro yustisia sehingga belum menimbulkan efek jera bagi pelaku pelanggaran sebagaimana dimaksudkan oleh pembentuk undang-undang.

Berdasarkan uraian tersebut diatas, maka dapat dikatakan bahwa pelaksanaan Undang-undang Nomor 6 Tahun 2011 tentang Keimigrasian mengenai tanggungjawab penjamin atas keberadaan dan kegiatan orang asing di Bali, belum berjalan efektif karena dipengaruhi oleh faktor substansi hukum, struktur hukum dan budaya hukum. Substansi hukum karena masih adanya norma konflik serta belum adanya hal yang mengatur kewajiban-kewajiban penajmin atas kegiatan orang asing serta belum jelasnya pengertian keberadaan dan kegiatan orang asing. Dari struktur hukum, para penegak hukum keimigrasian dalam memberikan tindakan pelanggaran keimigrasian lebih banyak memainkan peranan aktual berupa tindakan administratif keimirasian dari pada peranan yang seharusnya yaitu memberikan tindakan pro yustisia. dari faktor budaya hukum masih rendahnya ketaatan hukum penjamin yang disebabkan dari kedua faktor tersebut diatas yakni struktur hukum dan substansi hukum. 
Menurut pendapat Lawrence Friedman bahwa hukum merupakan suatu sistem. Sistem hukum terdiri dari tiga komponen yaitu struktur hukum, substansi hukum dan budaya hukum. Legal structure ( struktur hukum) di uraian sebagai berikut : structure, to be sure, is one basic and obvious element of the legal system...The structure of the system is its skeletal framework, it is the elements shape, the institusional body of the system.(struktur adalah salah satu dasar dan elemen nyata dari sistem hukum...struktur sebuah sistem adalah kerangka badanya, ia adalah bentuk permanennya, tubuh institusi dari sistem tersebut). yang kedua adalah legal substance uraiannya, the substance is composed of substantive rules and rules about how institusions should behave. (substansi tersusun dari peraturan-peraturan dan ketentuan mengenai bagaimana institusiinstitusi harus berperilaku). ${ }^{15}$ Dan ketiga legal culture (budaya hukum) uraian : legal culture refers, then to those parts of general social forces toward or away from the law and in particular ways. ${ }^{16}$ (kultur hukum mengacu pada bagian-bagian yang ada pada hukum, yakni adat kebiasaan, opini, cara bertindak dan berfikir yang mengarahkan kekuatankekuatan sosial menuju atau menjauh dari hukum dan dengan cara-cara tertentu).

\footnotetext{
${ }^{15}$ Lawrence M Friedman, 1975, The Legal System; A Social Science Perspektif, Rusell Sage Foundation, New York, p. 14

${ }^{16}$ Ibid, p. 15 .
}

Kaitannya dengan pelaksanaan Undang-undang Nomor 6 Tahun 2011 tentang Keimigrasian mengenai tanggung jawab penjamin atas keberadaan dan kegiatan orang asing di Bali, dengan menggunakan teori sistem hukum sebagai pisau analisis bahwa pelaksanaan hukum sangat ditentukan dalam hubungan yang serasi antara struktur hukum, substansi hukum dan budaya hukum, sehingga pelaksanaan aturan hukum dapat hidup demi tercapainya kesejahteraan masyarakat, ketertiban dan ketentraman. Pelaksanaan Undang-undang Nomor 6 Tahun 2011 mengenai tanggung jawab penjamin orang asing di Bali, dapat berjalan dengan baik jika ketiga komponen tersebut saling mendukung dan mampu melakukan pengendalian sosial.

\section{SIMPULAN DAN SARAN}

\subsection{Simpulan}

Berdasarkan pembahasan tersebut diatas, maka dapat diambil simpulan sebagai berikut:

1. Pelaksanaan Undang-undang Nomor 6 Tahun 2011 Tentang Keimigrasian mengenai tanggungjawab penjamin atas keberadaan dan kegiatan orang asing di Bali, belum berjalan efektif, yang disebabkan karena dalam pelaksanaan pemberian perpanjangan ijin tinggal kunjungan khususnya berkaitan dengan keharusan melampirkan surat penjaminan 
orang asing dari penjamin belum mengikuti ketentuan Pasal 140 Peraturan Pemerintah Nomor 31 Tahun 2013 tentang Peraturan Pelaksanaan UndangUndang Nomor 6 Tahun 2011 dan sebagian penjamin orang asing di Bali belum memahami akan kewajibankewajiban sebagaimana diatur dalam Undang-Undang Nomor 6 Tahun 2011 dan Peraturan Pemerintah Nomor 31 Tahun 2013.

2. Faktor-faktor yang mempengaruhi belum efektifnya pelaksanaan tanggung jawab penjamin atas keberadaan dan kegiatan orang asing di Bali, disebabkan oleh faktor (a) belum diatur secara jelas dan pasti kreteria penjamin, ada rumusan pasal yang tidak mengikuti asas berlakunya undang-undang dan belum diatur secara jelas dan pasti kewajibankewajiban penjamin khususnya berkaitan dengan kegiatan orang asing termasuk belum dijelaskan arti keberadaan dan kegiatan orang asing selama di Indonesia. (b) Penegak hukum imigrasi dalam menjalankan tugasnya lebih menekankan pada "peranan yang sebenarnya dilakukan" (actual role), yaitu memberikan tindakan administratif keimigrasian dari pada "peranan yang seharusnya" (expected role) yaitu memberikan tindakan pro yustisia bagi pelaku tindak pidana keimigrasian sehingga dirasa belum mencerminkan kepastian hukum. (c) Faktor budaya hukum, penjamin dan orang asing belum sepenuhnya mentaati ketentuan yang berlaku karena belum memahami peraturan keimigrasian. Begitu juga halnya partisipasi masyarakat Bali untuk melaporkan orang asing yang diketahui atau diduga berada di Bali secara tidak sah atau menyalahgunakan perizinan di bidang keimigrasian.

\subsection{Saran}

1. Kantor Imigrasi di Bali perlu memberikan sosialisasi hukum keimigrasian kepada penjamin dan orang asing secara terencana dan komprehensif. Sosialisasi hukum keimigrasian perlu juga diberikan kepada masing-masing Desa Pakraman di Bali khususnya yang banyak menerima kehadiran tamiu jaba negara (orang asing) dan tamiu jaba kuta (warga pendatang).

2. Direktorat Jenderal Imigrasi perlu melakukan revitalisasi hukum khususnya hal kreteria penjamin, kejelasan kewajiban penjamin atas kegiatan orang asing serta mengkaji hal orang asing pemegang izin tinggal kunjungan agar disamakan dengan pemegang visa kunjungan saat kedatangan yang dapat diperpanjangan hanya satu kali tanpa 
memiliki penjamin, kecuali kunjungan dalam rangka keluarga.

3. Kantor Imigrasi di Bali, semestinya dalam penegakan hukum keimigrasian menggunakan potensi dalam Undangundang keimigrasian untuk memberikan tindakan pro yustisia, bagi pelaku tindak pidana keimigrasian sehingga menimbulkan efek jera.

\section{DAFTAR PUSTAKA}

\section{Buku}

Astiti,Tjok Istri Putra, 2010, Desa Adat Menggugat dan Digugat, Udayana University Press, Denpasar.

Atmadja, I Dewa Gede, 2012, Hukum Konstitusi; Problema Konstitusi Indonesia Sesudah Perubahan UUD 1945, Setara Press, Malang.

Friedman, Lawrence M, 1975, The Legal System; A Social Science Perspektif, Rusell Sage Foundation, New York.

Rahardjo, Satjipto, 2010, Sosiologi Hukum ; Esai-Esai Terpilih, Genta Publishing, Yogyakarta.

Sadjijono. H, 2011, Bab-bab Pokok Hukum Administrasi, LaksBang Pressindo, Yogyakarta.

Santoso, M. Iman, 2004, Perspektif Imigrasi Dalam Pembangunan Ekonomi dan Ketahanan Nasional, Universitas Indonesia (UI-Press), Jakarta.

Soekanto, Soerjono, 2011, Faktor-Faktor Yang Mempengaruhi Penegakan Hukum, PT Rajagrafindo Persada, Jakarta.
Syahrani, H. Riduan, 2009, Kata-Kata Kunci Mempelajari Ilmu Hukum, PT. Alumni, Bandung.

Tim Prima Pena, Kamus Lengkap Bahasa Indonesia, Gita Media Press.

\section{Undang-Undang}

Undang-Undang Nomor 6 Tahun 2011 Tentang Keimigrasian.

Undang-Undang Nomor 12 Tahun 2011 Tentang Pembentukan Peraturan Perundang-Undangan.

Peraturan Pemerintah Nomor 31 Tahun 2013 Tentang Peraturan Pelaksana UndangUndang Nomor 6 Tahun 2013 Tentang Keimigrasian

Peraturan Daerah Nomor 3 Tahun 2001 Tentang Desa Pakraman.

\section{Internet}

Redaksi, 2012, Diminta Dua Naker Asing di Ocean Blue Diberhentikan, www.balipost.co.id/mediadetail.php?module $=$ berita\&kid=2sid=67286, diakses tanggal 10 Juni 2013.

Balipost, 2012, Naker Asing Merajalela, www.id.facebook.com/balipost, diakses tanggal 11 Februari 2014 